\title{
THE STUDY OF FEATURES OF CONTROL OF TECHNOLOGICAL PROCESS FOR RECEIVING THE APPLE SNACKS
}

\author{
Ivan Malezhyk \\ Department of Processes and Apparatus of Food Production \\ National University of Food Technologies \\ 68 Volodymirska str., Kyiv, Ukraine, 01601 \\ Igor Dubkovetskiy \\ Department of Processes and Apparatus of Food Production \\ National University of Food Technologies \\ 68 Volodymirska str., Kyiv, Ukraine, 01601 \\ dubkov78@ukr.net \\ Halyna Bandurenko \\ Department of Canning Technology \\ National University of Food Technologies \\ 68 Volodymirska str., Kyiv, Ukraine, 01601 \\ gbandurenko@yandex.ru \\ Tetyana Levkivska \\ Department of Canning Technology \\ National University of Food Technologies \\ 68 Volodymirska str., Kyiv, Ukraine, 01601 \\ talev_2111@mail.ru \\ Ljudmila Strelchenko \\ Department of Processes and Apparatus of Food Production \\ National University of Food Technologies \\ 68 Volodymirska str., Kyiv, Ukraine, 01601 \\ lanovenko2013@list.ru
}

\begin{abstract}
The article is devoted to the use of modern methods of the study of vegetable raw material for apple snacks production. To establish the optimal variety of apples there was used the analysis of technological parameters that depend on their chemical composition, especially on the quantity of dry substances, sugar-acid index and food fibers content. The study of inactivation degree of oxidative enzymes and possibility to prevent the protopectin hydrolysis process allowed establish the effectiveness of preliminary preparation of apples. The research-industrial drying setting, constructed by the authors, gave a possibility to study the different drying processes at the expanse of combination of convective and thermoradiative ways of energy supply and to establish the optimal regime of apple snacks drying.

This elaboration allows receive product with high organoleptic indices, shorten the drying process and lower specific energy consumption.

Keywords: drying, humidity content, apple snacks, energy supply, peroxidase, blanching, sugar syrup, convective, vitamin C.

\section{Introduction}

Recent time the snacks [1] - diverse chips, crackers, rusks, small loafs, grain flakes, dry breakfasts and some confectionaries (pastry, stick-like biscuits, special stick of confectionary and so on) become more and more popular among people. The main advantages of apple snacks are their full readiness for consumption, small sizes, compactness and high food value. 
The raw material with certain initial characteristics that directly depends on chemical composition and variety features of apples is suitable for snacks production. Especially, the important role is played by initial quantity of dry substances, sugar-acid index and food fibers content. The quality of ready product depends on technological process itself and regimes, which parameters are significant at each technological operation [2]. As far as organoleptic indices and food value of snacks remain the main ones at assessment of characteristics of ready product, all technological methods and ways of the raw material processing must be scientifically verified and accurately controlled. That is why the choice of proper methods of researches at each technological operation is a topical problem.

The aim of research - to outline the complex of significant criteria in technology of apple snacks production and to prove the effectiveness of studied parameters.

The tasks of research are to determine the changes of physical-chemical parameters of apples in the process of snacks production, to analyze them and establish the optimal technological regimes.

\section{Materials and Methods}

In the process of research were analyzed the modern winter varieties of apples, present on Ukrainian market such as Antonivka, Ligold, Champion, Golden, Semerenko, Renet, Pepin saffron.

Organoleptic parameters (color of flesh, consistence, mean size, taste, smell) were determined in sensor way. The percent ratio of flesh and seed chamber was determined by weighing of components.

The mass share of dry substances was determined by drying of batch to the stable mass [3].

The content of organic acids was determined by titration of extract by alkali, in recalculation for apple acid [4].

The content of sugars was determined by permanganate method [5].

For determination of vitamin $C$ the method of visual and potentiometric titration by 2,6-dychlorphenildophenol solution was used [6].

The content of mineral admixture (ashes) was determined by burning of batch [7].

The content of pectin was determined by titrometric method [8].

At apples processing the activity of oxidative enzymes, especially peroxidase was determined at each stage (operation).

The method of determination of peroxidase activity was the following. Vegetable material with mass 1-5 g was powdered in pounder with water (or with acetate buffer solution $\mathrm{pH} 5,4$ ) with capacity $50 \ldots 100 \mathrm{mg}$, transferred in volumetric flask for $25 \mathrm{ml}$ and added to the mark. The extract was kept for 5-10 min for guaranteed extraction of extractive substances and centrifuged during $10 \mathrm{~min}$ at rotation frequency $3000 \mathrm{rev} / \mathrm{min}$ that provides the separation of suspended particles. $2 \mathrm{ml}$ of extract, $2 \mathrm{ml}$ of buffer solution $2 \mathrm{ml}$ of benzidine were poured in each of two dishes with width $2 \mathrm{~cm}$. Dishes were put in dishes-holder of photocolorimeter DPC2 (Russia): one (control), second (experiment). $2 \mathrm{ml}$ of water were poured in control dish, $2 \mathrm{ml}$ of $0,03 \%$ solution of hydrogen peroxide were poured in experimental one by the pipette with broad beak. Stopwatch was switched on synchronously with falling of first drop. In experimental dish the solution became blue and indicator moved to the null position. The time was registered from the beginning of adding hydrogen peroxide to the reaching of given optic density (null position) by the solution.

The enzyme activity was calculated by the formula (1):

$$
\mathrm{A}=\mathrm{D} \frac{\alpha \times \beta \times \gamma}{\mathrm{t} \times \mathrm{d}},
$$

where D - optic density, equal to 0,250; $\mathrm{d}$ - width of liquid layer (width of dish), cm; $\mathrm{t}$ - time, s; $\alpha$ - ratio of quantity of liquid, taken for extract preparation, ml, to batch mass, $g$; $\beta$ - degree of additional dilution of extract (in correspondent cases); $\gamma$ - degree of constant dilution of extract in reactionary mixture (at given conditions -4 ). 
The choice of apples was realized as following. At selection of apples varieties for snacks production the attention was paid to the ones, contained the big quantity of food fibers, in first turn, cellulose and protopectin - Champion, Golden, Semerenko. These substances provide the necessary elastic structure during whole technological process, at both blanching and drying.

As the result of preliminary studies of physical-chemical composition of apples the apple variety Champion was chosen (Fig. 1).

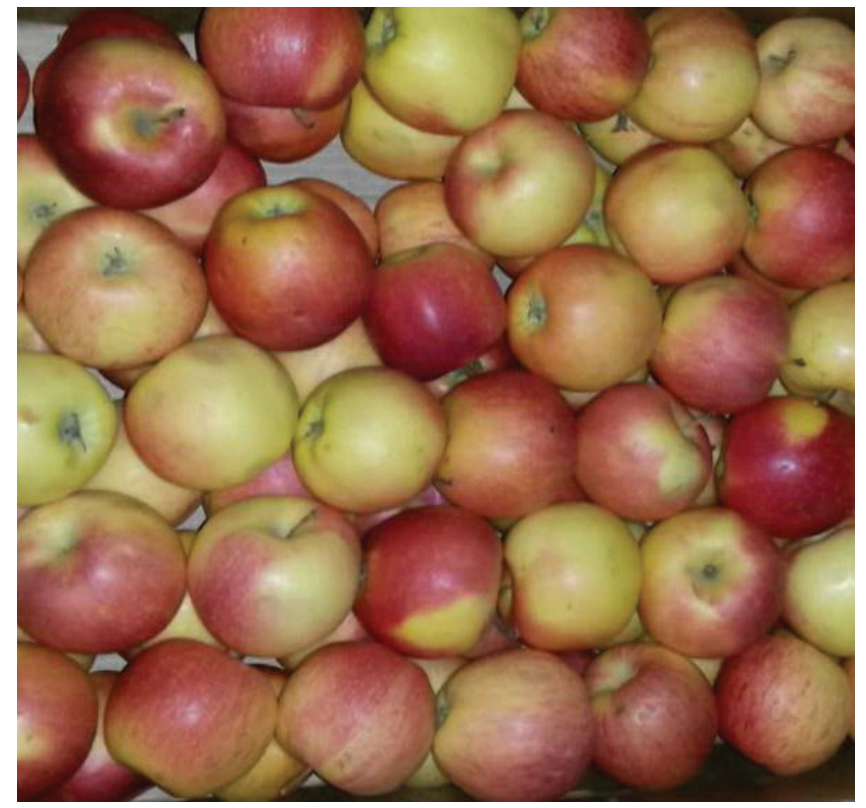

Fig. 1. Apples of the variety Champion

The study of chemical composition of this variety of apples showed the essential content of dry substances, food fibers and sugar-acid index (ratio of sugars quantity to organic acids) - within 10 (Table 1).

\section{Table 1}

Chemical composition of apples Champion

\begin{tabular}{cc}
\hline Name of parameter & Apples (edible part) \\
\hline Dry substances of apples, \% & $13,5-13,75$ \\
Mono and disaccharides, \% & $10,0-10,2$ \\
Organic acids , \% & $0,48-0,5$ \\
Pectin substances, \% & $0,9-1,0$ \\
Cellulose, \% & $0,8-0,9$ \\
Mineral substances, \% & $0,7-0,8$ \\
Vitamin C, mg \% & $3,5-4,0$
\end{tabular}

To receive snacks, the apples Champion were washed, inspected, cleaned of inedible parts and cut in plates with width 3-5 mm. The pieces of apples were blanched in sugar syrup of different concentration from $15 \%$ to $70 \%$, cooled to $30{ }^{\circ} \mathrm{C}$ and dried by different ways - convective, thermoradiative and their combination to the dry substances content $85 \%$.

According to preliminary studies [9-12] the combined convective thermoradiative method was used for intensification of drying process and establishing of optimal regime. 
The combined drying [13-15], realized on research-industrial drying setting, constructed by the lecturers of the department of process and apparatuses of food production of National university of food technologies, Dubkovetskiy I. V. and Malezhyk I. F. was offered to raise quality, preserve biologically active substances of the raw material and also to decrease the influence of oxidative processes on product [16].

The scheme of drying setting is presented on the Fig. 2, its appearance - on the Fig. 3. The drying setting is a chamber 1 , made of plates of polished aluminum with high coefficient of IR rays reflection 0,86 that improves the conditions of creation of uniform raying of dried object. The air flow moves under effect of ventilator vanes 2, passes gradually through external heater 3 and drying chamber 1 where contacts with material supplying the heat and removing the evaporated moisture.

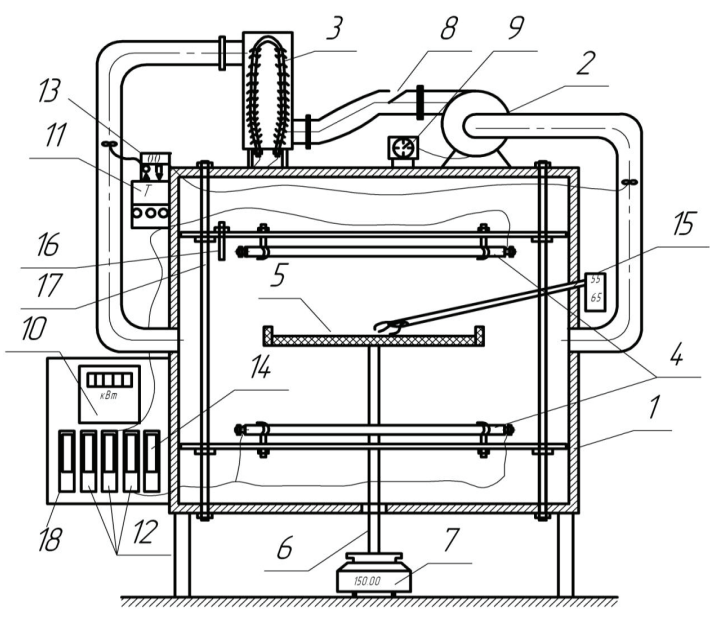

Fig. 2. The scheme of experimental drying setting: 1 - drying chamber; 2 - ventilator; 3 - heater; 4 - IR-generators; 5 - box-like netted basket; 6 - bar; 7 - analytic weighs; 8 - shutter of air recirculation; 9 - speeds variator; 10 - electric energy meter; 11 - temperature controller; 12 - automatic switching of heater, upper and low IR-generators; 13 - relative humidity generator; 14 - ventilator automatic switching; 15 - thermometer with thermocouples; 16 - temperature contact sensor; 17 - regulating device of IR-generators joints position;

$$
18 \text { - IR-generators switching relay }
$$

The dried material (raw material) was placed on special net-support in box-like netted basket 5, fixed in the corpus of drying chamber 1 for further raying by radiative-infrared radiators 4 .

The joints of IR generators can move on vertical directing lines 17 and be fixed in different positions that give a possibility to change the value of radiation of samples and volume of working chamber. Construction of joint of IR radiators allows use both "light" and "dark" IR generators for drying products.

The setting provides combining radiative-convective method of drying food products. For that the heated air is supplied over the dried object with certain speed, which value is regulated by the block of automatic regulation of movement of heat carrier 9 and electric ventilator 2 . The joint of registration of decrease of dried material is a modified construction of analytic weighs 7 , combined by the bar 6 with box-like netted basket 5 .

The temperature of heat agent and diapason of switching of TEHs that changes time of product x-raying is set on the block of temperature automatic regulation 11 . The energy consumption for kilogram of ready product or kilogram of evaporated moisture is realized by the meter 10 . Recirculation of air is realized using the shutter 8 . The change of relative humidity of air on input and output of drying chamber is fixed and regulated using the block of automatic regulation of relative humidity 13. The heater and IR-generators can be de-energized by automatic switching 12 . The change of temperature in cross-cut of product is measured by thermometer with thermocouples 15 .

The drying is carried out in impulse heating-cooling regime, at that the heating is realized by IR-rays and external convective TEH to the given humidity with wave length in diapason 
1,2-4 mcm with flow density $2-15 \mathrm{kWatt} / \mathrm{m}^{2}$. After reaching the set limit temperature of drying IR-radiators and external heater are switched off and turned to the regime of impulse switching. The durations of impulse switching and pause correlate as 1:1, 1:2, 1:3 and so on and depend on the type of material and limit temperature in drying chamber, set according to sensor.

The temperature is fixed by temperature contact sensor 16 and signal of switching of IR-generators is sent on relay 18. As soon as drying temperature reaches the given value, the radiators 4 are switched off and material begins to cool down. At cooling material to the limit value of temperature, radiators 4 are switched on automatically, and drying process continues analogously to aforesaid till material reaches the given humidity.

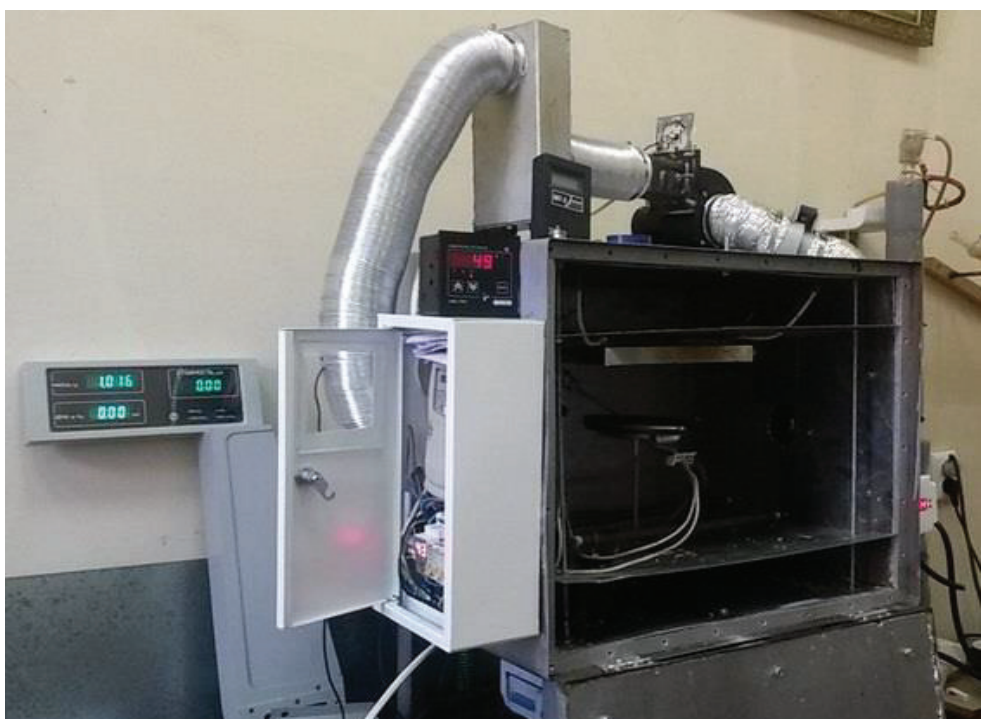

Fig. 3. Appearance of research-industrial drying setting

\section{1. Experimental procedures}

For establishing of optimal organoleptic parameters of snacks it is necessary to carry out preliminary preparation of apples that must provide the maximal possible peroxidase inactivation, partial protopectin hydrolysis and satiation of apple pieces with sugar syrup. The blanching of prepared apples in different concentrations of sugar syrup from $15 \%$ to $70 \%$ with addition of lemon and ascorbic acids was studied. At that the initial content of dry substances had been 13,5\% and changed after blanching depending on sugar syrup concentration. Having analyzed the received samples, the better organoleptic indices (light-yellow color, elastic and cracking consistence) were inherent to the ones, blanched in $40 \%$ sugar syrup. The samples, blanched in sugar syrup of less concentration had less expressed taste and the ones, blanched in sugar syrup with concentration more than $40 \%$, had wrinkled consistence and some hardness at chewing. The apple pieces, prepared in such a way, were dried.

The studies in wider diapason showed the expedience of the following regime of prepared apples drying [17-19]. The first stage was carried out in impulse regime of heating-cooling, at that heating was carried out by convective-thermoradiative energy supply using infrared (IR) radiation with wave length in diapason $1,2-4 \mathrm{mcm}$ and flow density $5,5-6,0 \mathrm{kWatt} / \mathrm{m}^{2}$ to the reaching limit temperature in first period $70-75^{\circ} \mathrm{C}$, and cooling was realized for $100-110 \mathrm{~s}$. Duration of first period was 20-25 min. In second period the additional drying was carried out by convective method at limit temperature $40-45^{\circ} \mathrm{C}$. Temperature was fixed by the compact temperature sensor, after that signal was sent on switching relay of convective TEHs. As soon as temperature reaches the given value, TEHs were switched off and material started to cool down at working ventilator. After reaching the humidity content $35 \%$ product was kept in chamber to the humidity content $10-12 \%$.

The received samples (Fig. 4) was cooled, inspected and analyzed. 


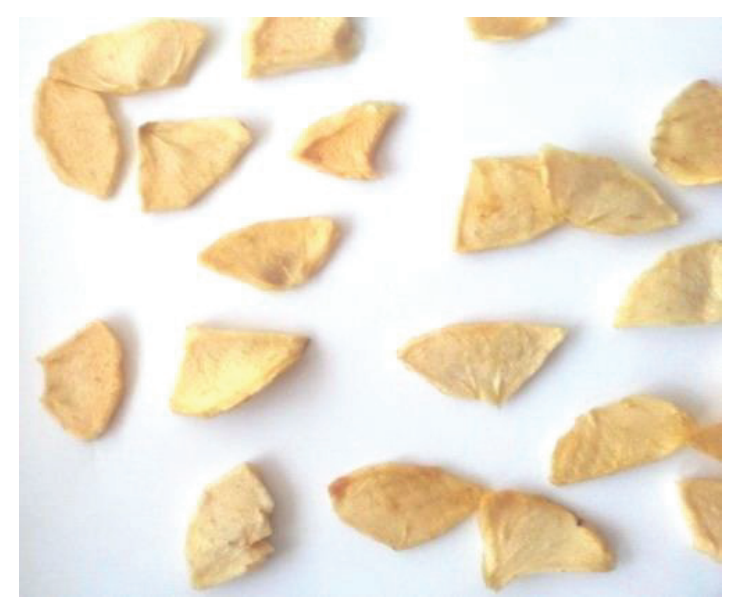

Fig. 4. Apple snacks, received by improved technology of combined energy supply

\section{Results}

The use of combined convective-thermoradiative drying of apple snacks favors the saving of electric energy at the expanse of acceleration of technological process in 1,3-1,5 times and preservation of biologically active substances of the raw material.

The advantages of given studies are the use of constructed research-industrial drying setting that allows use the study in wide diapason directly at drying process. At that experimenter has a possibility to change temperature, speed of air flow, strain on TEHs, to establish automatic impulse regime "heating-cooling", detect the energy consumption at any moment of drying.

The received results of research can be useful for technologists of food enterprises, connected with production or use of fruit semi-products in food technologies.

\section{Conclusions}

1. On the base of the studies it was recommended to use winter apple variety Champion that is characterized with high organoleptic indices and essential content of food fibers for snacks production.

2. To improve organoleptic indices and vitaminization of product the preliminary preparation of apples was offered - blanching in sugar syrup with sugar concentration $40 \%$ and addition of lemon and ascorbic acids.

3. The dynamics of peroxidase inactivation in the process of apples blanching was studied. It was established, that blanching and drying provide the decrease of activity to 0,36 activity units for $1 \mathrm{~g}$ of product.

4. The optimal parameters of snacks drying were established, namely: first period -in impulse heating-cooling regime by convective-thermoradiative energy supply at temperature $70-75^{\circ} \mathrm{C}$, second (additional drying) - by convective method at temperature $40-45^{\circ} \mathrm{C}$.

5. These methods of research are universal and satisfy the set tasks. But the use of express-methods of research is wanted.

6. The studies may be useful at production of snacks of other fruit-vegetable raw material.

\section{References}

[1] Kalinina, I. V., Ruskina, A. A. (2014). Modern approaches to technology safe snack products. Bulletin of South Ural State University. Series: Food and Biotechnology, 3 (2), 29-36.

[2] Strelnikov, A. (2015). Innovative approaches to processing fruit production. Technology and Food processing industry. Agribusiness - healthy food, 1 (5), 95-101.

[3] DSTU 7804:2015. Produkty pererobljannja fruktiv ta ovochiv. Metody vyznachannja suhyh rechovyn abo vology (2016). Kyiv: DP «UkrNDNC», 20.

[4] DSTU 4957:2008. Produkti pereroblennya fruktiv ta ovochiv. Metodi viznachennya titrovanoi kislotnosti (2009). Kyiv: DP «UkrNDNC», 14. 
[5] DSTU 4954:2008. Produkti pereroblennya fruktiv ta ovochiv. Metodi viznachannya tsukriv (2009). Kyiv: DP «UkrNDNC», 22.

[6] DSTU 7803:2015. Produkti pereroblennya fruktiv ta ovochiv. Metodi viznachannya vitaminu C (2016). Kyiv: DP «UkrNDNC», 24.

[7] DSTU 4913:2008. Frukti, ovochI ta produkti pereroblennya. Metodi viznachennya mineralnih domishok (2009). Kyiv: DP «UkrNDNC», 12.

[8] DSTU 8069:2015. Produkti pereroblennya fruktIv ta ovochIv. Titrimetrichniy metod viznachennya pektinovih rechovin (2016). Kyiv: DP «UkrNDNC», 14.

[9] Malezhyk, I. F., Dubkovetskiy, I. V., Burlaka, T. V. (2016). Patent UA 111659 IPC A23B 7/02, F26B 3/04, F26B 3/30, F26B 7/00. The method of drying cultivated mushrooms combined supply of energy. Assignee: National university of food technologies; № 201411439; declareted: 20.10.2014. Bul.10.

[10] Dubkovetskiy, I. V., Malezhyk, I. F., Shevchuk, O. O. (2014). Investigation of the kinetics of drying pears combined supply of energy. Scientific works, 45 (2), 60-64.

[11] Bessarab, A. S., Bandurenko, G. M., Dubkovetskiy, I. V., Pisarev, M. G. (2014). Features production of dried potatoes combined method. Safety and quality of food materials II International practical Scientific Conference. Kyiv: NSC "IAE”, 104-107.

[12] Burlaka, T. M., Dubkovetskiy, I. V., Malezhyk, E. F. (2015). Research drying various cultivated mushrooms infrared emitters. Scientific works, 47 (2), 12-17.

[13] Strelchenko, L. V., Burlaka, T. V., Pisarev, M. V., Dubkovetskiy, I. V., Bandurenko, G. M., Malezhyk, I. F. (2015). Innovative method of drying fruit and vegetable raw materials. International scientific conference of young scientists and students NUFT «Scientific achievements of young people - solving the problems of human nutrition in the XXI Century». Part 2. Kyiv, 178.

[14] Malezhyk, I. F., Dubkovetskiy, I. V., Bandurenko, G. M., Strelchenko, L. V.; (2016). Patent UA 8357827. The method of manufacturing apple snacks. Assignee: National university of food technologies. № u 2015 07404; declareted: 23.07.2015; published: 10.03.2016. Bul. 5. Available at: http://uapatents. com/5-105128-sposib-virobnictva-yabluchnikh-snekiv.html

[15] Malezhyk, I. F., Dubkovetskiy, I. V., Bandurenko, G. M., Strelchenko, L. V. (2015). Investigation of convective drying of apples, thermoradiation and combined methods. Voronezh, 493.

[16] Dubkovetskiy, I. V., Malezhyk, I. F., Burlaka, T. V., Strelchenko, L. V.; (2016). Radiation convective drying installation. Patent UA 112348, IPC МПК F26B 3/30, F26B 3/04, F26B 9/06, F26B 21/04, F26B 21/08, F26B 21/10, F26B 21/12, A23B 7/02. Assignee: National university of food technologies. № a 201411435; declareted: 20.10.2014; published: 25.08.2016. Bul. 16 . 